\title{
Effect of corn silage hybrids differing in starch and neutral detergent fiber digestibility on lactation performance and total-tract nutrient digestibility by dairy cows
}

\author{
L. F. Ferraretto, ${ }^{*}$ A. C. Fonseca, ${ }^{*}$ C. J. Sniffen,† A. Formigoni, $\ddagger$ and R. D. Shaver ${ }^{* 1}$ \\ ${ }^{*}$ Department of Dairy Science, University of Wisconsin, Madison 53706 \\ †Fencrest LLC, Holderness, NH 03245 \\ fDipartimento di Scienze Mediche Veterinarie, Università di Bologna, 40084 Bologna, Italy
}

\begin{abstract}
Selection for hybrids with greater starch and NDF digestibility may be beneficial for dairy producers. The objective of this study was to determine the effect of feeding a TMR containing a floury-leafy corn silage hybrid (LFY) compared with a brown midrib corn silage hybrid (BMR) for intake, lactation performance, and total-tract nutrient digestibility in dairy cows. Ninetysix multiparous Holstein cows, $105 \pm 31 \mathrm{~d}$ in milk at trial initiation, were stratified by DIM and randomly assigned to 12 pens of 8 cows each. Pens were randomly assigned to 1 of 2 treatments, BMR or LFY, in a completely randomized design; a 2 -wk covariate period with cows fed a common diet followed by a 14wk treatment period with cows fed their assigned treatment diet. Starch digestibilities, in situ, in vitro, and in vivo, were greater for LFY compared with BMR; the opposite was observed for NDF digestibility. Cows fed BMR consumed $1.7 \mathrm{~kg} / \mathrm{d}$ more dry matter than LFY. Although, actual-, energy-, and solids-corrected milk yields were greater for BMR than LFY, feed conversions ( $\mathrm{kg}$ of milk or component-corrected milk per $\mathrm{kg}$ of DMI) did not differ. Fat-corrected milk and milk fat yield were similar, as milk fat content was greater for cows fed LFY (4.05\%) than BMR (3.83\%). Cows fed BMR had lower milk urea nitrogen concentration, but greater milk protein and lactose yields compared with LFY. Body weight change and condition score were unaffected by treatment. Total-tract starch digestibility was greater for cows fed the LFY corn silage; however, dry matter intake and milk and protein yields were greater for cows fed the BMR corn silage. Although total-tract starch digestibility was greater for cows fed the LFY corn silage, feed efficiency was not affected by hybrid type due to greater dry matter intake and milk and protein yields by cows fed the BMR corn silage.
\end{abstract}

Received April 14, 2014

Accepted October 8, 2014.

${ }^{1}$ Corresponding author: rdshaver@wisc.edu
Key words: corn silage, digestibility, fiber, starch

\section{INTRODUCTION}

Whole-plant corn silage (WPCS) is typically comprised of 25 to $35 \%$ starch and 40 to $50 \%$ NDF (DM basis; NRC, 2001). Thus, increasing starch and NDF digestibility of WPCS may improve lactation performance by dairy cows fed corn silage-based diets (Oba and Allen, 1999; Ferraretto and Shaver, 2012b). The digestibility of starch in WPCS is influenced by a starchprotein matrix (Kotarski et al., 1992), which restricts digestion by microorganisms in the rumen (McAllister et al., 1993), whereas NDF digestibility is limited primarily by the cross-linking of lignin to other fibrous components (Jung et al., 2012).

Several factors, including nitrogen fertilization, maturity at harvest, kernel processing, and ensiling period length, influence the starch-protein matrix in corn kernels (Masoero et al., 2011; Der Bedrosian et al., 2012; Ferraretto and Shaver, 2012a,b) and hence starch digestibility in WPCS. Additionally, selection for WPCS hybrids that contain more floury-type endosperm may allow for an increase in starch digestibility (Philippeau and Michalet-Doreau, 1997; Correa et al., 2002). Greater starch digestibility results in increased energy availability for dairy cows and thereby greater milk production, feed efficiency, or both (Firkins et al., 2001; Ferraretto et al., 2013). Therefore, WPCS hybrids selection for enhanced starch digestibility may improve milk production per area of crop produced and thereby profitability of dairy farms.

Improvements in NDF digestibility through varying harvest practices are possible but inconsistent or minimal (Ferraretto and Shaver, 2012b). However, selection of WPCS hybrids for high NDF digestibility, brown midrib (BMR) hybrids in particular, has improved lactation performance by dairy cows (Oba and Allen, 2000a,b). Selection of WPCS hybrids with highly digestible NDF can reduce the effects of rumen fill in high-producing cows, thereby allowing for increased 
intake and milk production (Mertens, 1987; Oba and Allen, 1999).

Comparisons between WPCS hybrids containing high NDF digestibility versus high starch digestibility fed to lactating dairy cows are not available in the research literature. This comparison may provide information for better decision making on hybrid selection by dairy producers and their nutritionists. Therefore, the objective of this study was to determine the effect of feeding a TMR containing a floury-leafy WPCS hybrid (LFY) compared with WPCS from a BMR hybrid on intake, lactation performance, and total-tract nutrient digestibility by dairy cows. We hypothesized that feeding a WPCS hybrid with high starch digestibility would result in increased total-tract starch digestibility and thereby improved milk production or feed efficiency $(\mathrm{kg}$ of milk/kg of DMI) by lactating dairy cows.

\section{MATERIALS AND METHODS}

\section{Silage Production}

Floury-leafy (GLF97, Glenn Seed Ltd., Blenheim, ON, Canada) and BMR (F2F485, Mycogen Seeds, Dow AgroSciences LLC, Indianapolis, IN) WPCS hybrids were planted in separate field plots $(6.5$ ha at 69,000 seeds/ha for LFY and 5.8 ha at 79,000 seeds/ha for $\mathrm{BMR}$ ) at the University of Wisconsin-Arlington Agricultural Research Station (UWAARS; Arlington, WI) on May 21, 2012, and grown under the same tillage, fertilizer application, and weed control practices. Fields of LFY and BMR were harvested on September 7 and 14, 2012, respectively, using a self-propelled forage harvester (JD 6910, John Deere, Moline IL) set for a 1.95-cm theoretical length of cut and equipped with conventional processing rolls set for a 2-mm gap spacing, stored in separate side-by-side $2.5-\mathrm{m}$ diameter by $76-\mathrm{m}$ long silo bags, and allowed to ferment for approximately $30 \mathrm{~d}$ before commencing the feeding trial. Targeted DM content of WPCS at harvest was 35\%. Neither LFY nor BMR was treated with a silage inoculant. Total tons of DM harvested per hectare were 15.2 and 13.7 from LFY and BMR, respectively. However, because these were not replicated field plots, statistical evaluation of the yield observation is not possible and thus a valid comparison of the potential economic impact of the yield difference cannot be performed.

\section{Kernel Sample Collection and Analysis}

On the day of harvest, 10 random ears were sampled from LFY and BMR fields for kernel characterization. Ear samples were husked and stored in a $-20^{\circ} \mathrm{C}$ freezer. All 10 ears were hand shelled while frozen and composited into one sample. Samples were sent to the University of Wisconsin Soil and Forage Analysis Laboratory (Marshfield, WI) in duplicate for the analyses described below. Samples were dried at $40^{\circ} \mathrm{C}$ for 72 $\mathrm{h}$ in a forced-air oven to determine DM content; low temperature was used to maintain intact the kernel cell structure (Philippeau and Michalet-Doreau, 1997). Dried samples were analyzed for vitreousness using a light box (Vivek et al., 2008), zein protein profile (Nellis et al., 2013), and in vitro gas production (as described by Hoffman et al., 2012). In vitro gas production was measured on duplicate $0.5 \mathrm{~g}$ of dried and $1-\mathrm{mm}$ ground corn samples using the Ankom-RFS system (Ankom Technology Corp., Macedon, NY) with wireless transponders. Samples were adjusted for the gas production of a blank sample.

\section{Animals and Treatments}

The animal research was conducted at the University of Wisconsin-Madison Arlington Blaine Dairy under a protocol approved by the Institutional Animal Care and Use Committee of the College of Agricultural and Life Sciences. Ninety-six multiparous Holstein cows were stratified by DIM $(105 \pm 31$ DIM at trial initiation) and randomly assigned to 12 pens of 8 cows each in the University of Wisconsin sand-bedded freestall barn and milking parlor dairy (Emmons Blaine Dairy Research Center, Arlington, WI). Pens were randomly assigned to 1 of 2 treatments in a completely randomized design with covariate adjustment; a 2-wk covariate period with pens fed a common diet followed by a 14-wk treatment period with cows fed their assigned treatment diets. The covariate period diet contained (DM basis) nonexperimental corn silage (26.6\%), alfalfa silage $(18.6 \%)$, high-moisture shelled corn $(11.7 \%)$, whole cottonseed $(6.5 \%)$, dried distillers grain $(4.5 \%)$, and concentrate mixture (34.0\%). Experimental diets were formulated using the model CNCPS 6.1 (Tylutki et al., 2008) in the NDS platform (RUM\&N, Sas, Italy) and are provided in Table 1 . The same concentrate mixture, prepared at the University of Wisconsin Feed Mill (Arlington), was used in both diets. On wk 8 of the treatment period, the LFY diet was adjusted to contain similar concentrations of lignin as the BMR diet by replacing wheat straw with LFY WPCS. Diets were fed as TMR mixed once daily at 8 a.m. for $5 \%$ refusal with daily DMI determined on individual pens throughout the 16-wk experiment. Daily pen intake was measured as the difference between the amount of as-fed TMR offered and the amount of as-is orts using the Feed Supervisor Software (Supervisor Systems, Dresser, WI), with that amount then multiplied by the DM content of the TMR to determine DMI. Measurements 
Table 1. Ingredient and nutrient composition (means \pm SD) of the experimental $\operatorname{diets}^{1}$

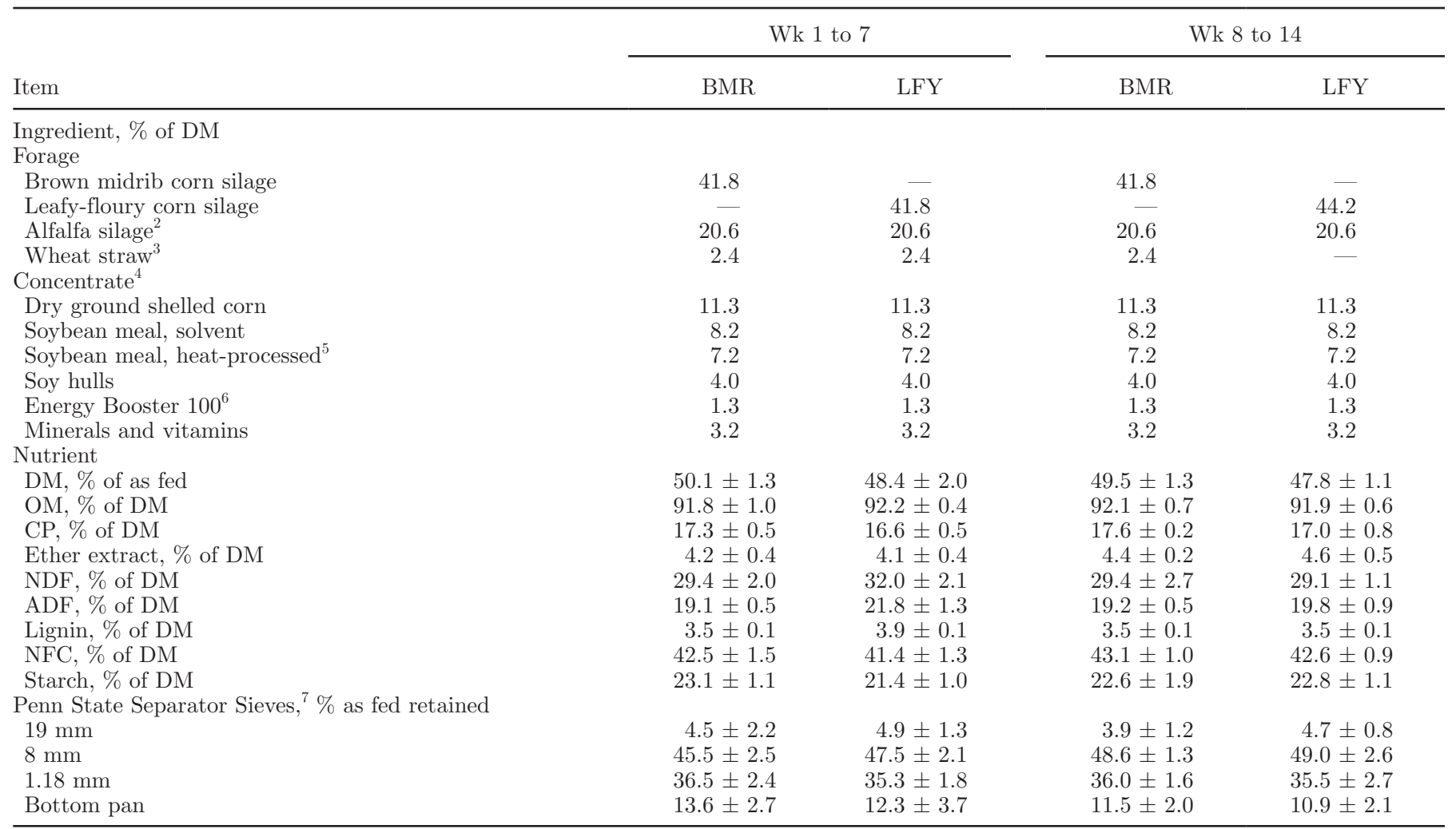

${ }^{1}$ Treatments were diet containing brown midrib (BMR) or leafy-floury (LFY) hybrid.

${ }^{2}$ Contained $21.8 \%$ CP, $29.5 \%$ ADF, 33.8\% NDF, and 3.3\% ether extract (DM basis).

${ }^{3}$ Contained $4.5 \% \mathrm{CP}, 52.4 \% \mathrm{ADF}, 75.8 \% \mathrm{NDF}$, and $1.5 \%$ ether extract (DM basis).

${ }^{4}$ Contained $24.7 \%$ CP, $27.5 \%$ NDF, and $27.4 \%$ starch (DM basis).

${ }^{5}$ SoyPLUS (West Central Cooperative, Ralston, IA).

${ }^{6}$ Minimum of $98 \%$ total fatty acids (MSC Company, Dundee, IL).

${ }^{7}$ Particle size was measured using the Penn State Particle Size Separator as described by Kononoff et al. (2003).

of DMI were adjusted for orts only during digestibility weeks. The TMR were pushed up 3 times daily (0530, 1200, and $2000 \mathrm{~h}$ ). All cows were injected with bovine somatotropin (Posilac, Monsanto Company, St. Louis, $\mathrm{MO}$ ) every $14 \mathrm{~d}$ beginning the first day of the covariate period.

\section{Sample Collection and Analysis}

Body weight and condition score (Wildman et al., 1982) were recorded for pens on 1 d every 2 wk throughout the 16-wk trial. Daily BW change (BWC) for individual cows were determined by linear regression of BW measurements over time. Milk yield was recorded daily (DairyComp305, Valley Agricultural Software, Tulare, CA) on individual cows milked 2 times daily (0500 and $1600 \mathrm{~h}$ ) in a double-16 parlor (Metatron P21, GEA Farm Technologies, Bakel, the Netherlands) throughout the 16-wk trial and composited by pen by week before statistical analysis. Milk samples were obtained from all cows every other week on the same 2 consecutive days from the a.m. and p.m. milkings throughout the 16-wk trial. Samples were composited by pen by week, and composites analyzed for fat, true protein, lactose, and MUN concentrations and SCC by infrared analysis (AgSource Milk Analysis Laboratory, Menomonie, WI) using a Foss FT6000 (Foss Electric, Hillerød, Denmark). Average daily yields of fat, protein, and lactose were calculated from these data for each week. Yields of 3.5\% FCM, SCM, and ECM were calculated according to NRC (2001) equations. Actual-milk, 3.5\% FCM, SCM, and ECM feed conversions were calculated by week using average daily yield and DMI data. Dietary energy concentrations (Mcal of $\mathrm{NE}_{\mathrm{L}} / \mathrm{kg}$ of $\mathrm{DM}$ ) were calculated by summing the megacalories of $\mathrm{NE}_{\mathrm{L}}(\mathrm{NRC}$, 2001) estimated from actual milk production, required for maintenance (based on actual BW) and in actual BWC, and then dividing the sum by DMI.

Samples of TMR, LFY, BMR, alfalfa silage, wheat straw, and concentrate mix were obtained weekly and 
composited for the covariate period and every $2 \mathrm{wk}$ during the treatment period for analysis. Samples for determination of nutrient composition were dried at $60^{\circ} \mathrm{C}$ for $48 \mathrm{~h}$ in a forced-air oven to determine $\mathrm{DM}$ content, ground to pass a 1-mm Wiley mill screen (Arthur H. Thomas, Swedesboro, NJ) screen, and composited as described before sending to Cumberland Valley Analytical Services Inc. (CVAS; Maugansville, MD) for nutrient analysis. Absolute DM was determined by oven-drying at $105^{\circ} \mathrm{C}$ (forages) or $135^{\circ} \mathrm{C}$ (concentrates and TMR) for $3 \mathrm{~h}$ (method 930.15, AOAC International, 2006 or NFTA method 2.2.2.5, Shere et al., 2006). All samples were analyzed for DM, OM (method 942.05; AOAC International, 2006), CP (method 990.03; AOAC International, 2006), ether extract (method 2003.05; AOAC International, 2006), NDF using $\alpha$-amylase and sodium sulfite (Van Soest et al., 1991), ADF (method 978.10; AOAC International, 2006), starch (Hall, 2009), and particle size. Particle sizes of TMR, LFY, BMR, and alfalfa silage samples were determined as described by Kononoff et al. (2003). Particle size of the concentrate mixture was determined by dry sieving using a Tyler Ro-Tap Shaker Model RX-29 (Mentor, OH) with sieves of 4,760, 2,380,1,191, 595, 297, 149, and $63 \mu \mathrm{m}$ apertures plus bottom pan; mean particle size (MPS) was calculated using a log normal distribution (Baker and Herrman, 2002). Minerals (method 985.01; AOAC International, 2006), borate-phosphate buffer soluble CP (Krishnamoorthy et al., 1982), ruminal in vitro NDF (30 and $240 \mathrm{~h}$ ), and starch (7 h) digestibilities on LFY and BMR samples were also determined at CVAS. The 30- and 240-h in vitro NDF digestibility on dried 1-mm screen ground samples was performed using the method of Goering and Van Soest (1970) and used to calculate rate of digestibility $\left(\mathbf{k}_{\mathrm{d}}\right.$; Van Amburgh et al., 2003) and undigested NDF (uNDF), respectively. Ruminal in vitro starch digestibility at $7 \mathrm{~h}$ on dried 4-mm screen ground samples was determined using procedures modified from Richards et al. (1995). Using undried, unground samples of LFY and BMR, corn silage processing score (Ferreira and Mertens, 2005) and fermentation profile were determined at CVAS. For fermentation profile analysis, $25 \mathrm{~g}$ of wet sample was diluted with $200 \mathrm{~mL}$ of deionized water, blended for 2 min, and filtered. The extract was collected and used for determination of $\mathrm{pH}$, ammonia- $\mathrm{N}$, lactic acid, and other organic acids. The $\mathrm{pH}$ was measured by adding $30 \mathrm{~mL}$ of water extract to a Mettler DL12 Titrator (Mettler-Toledo, Columbus, OH). Ammonia-N was measured by adding a mixture containing $25 \mathrm{~mL}$ of water extract and $75 \mathrm{~mL}$ of deionized water into a Labconco Rapidstill II (model 65200, Labconco, Kansas City, MO) and the mixture was titrated with $0.1 \mathrm{~mL}$ of $1 \mathrm{~N} \mathrm{HCl}$. Lactic acid was analyzed using an YSI
2700 Select Biochemistry Analyzer (YSI Inc., Yellow Springs, OH). A PerkinElmer gas chromatograph with a Restak column packed with Stabilwax-DA (Perkin Elmer, Shelton, CT) was used for other organic acid analysis.

Total-tract DM, OM, CP, NDF, and starch digestibilities were determined using lignin (method 973.18; AOAC International, 2006) as an internal marker. Six fecal grab samples were collected from each cow at 8 to 12 -h intervals covering every 4 -h clock period over 3 consecutive days during the last week of the covariate period and wk 7 and 13 of the treatment period. This method was previously used by Gencoglu et al. (2010) and Ferraretto et al. (2012). Ort samples were collected daily during the fecal sampling period. Treatment TMR, fecal, and ort samples were composited by week (TMR samples), pen within week (ort samples), or cow within pen within week (fecal samples); the composited samples were analyzed for DM, OM, CP, NDF, starch, and lignin as previously described. Total-tract nutrient digestibilities were calculated from lignin and nutrient concentrations in the orts-adjusted diet and feces using the following equation:

apparent total-tract nutrient digestibility

$(\%$ of nutrient intake $)=100-[($ TMR marker

concentration/fecal marker concentration $) \times($ fecal

nutrient concentration/TMR nutrient concentration)].

Feed sorting was evaluated during 3 consecutive days during wk 7 and 13 of the treatment period. Individual daily pen samples (TMR and orts) were analyzed for particle size as described by Kononoff et al. (2003). Sorting was calculated as the actual intake of each fraction expressed as a percentage of the predicted intake as described by Leonardi and Armentano (2003); values $<100 \%$ indicate selective refusal, $>100 \%$ indicate preferential consumption, and equal to $100 \%$ indicate no sorting.

A subsequent in situ ruminal digestion trial was conducted in the University of Wisconsin campus tiestall barn (Dairy Cattle Center, Madison, WI) using 3 ruminally cannulated mid-lactation multiparous Holstein cows fed a TMR containing (DM basis) alfalfa silage $(44.5 \%)$, nonexperimental corn silage $(26.8 \%)$, alfalfa hay $(10.7 \%)$, wheat straw $(6.5 \%)$, and concentrate mixture (11.5\%). Individual WPCS samples from each treatment from wk 7 and 13 of the lactation trial were evaluated for starch (12-h) and NDF (24-h) in situ digestibilities. Dacron polyester cloth bags $(9 \times 18 \mathrm{~cm})$ containing 5-g DM samples (approximately $15 \mathrm{~g}$ as fed) of respective treatments were incubated in duplicate 
within each cow using undried and unground samples. The in situ bags for the respective treatments for each time point were placed in a nylon laundry bag $(30 \times$ $40 \mathrm{~cm}$ ) and then positioned in the ventral rumen. Bags were moistened in warm water before incubation. Each laundry bag contained a blank bag to allow correction for any infiltration of DM into sample bags. After removal, samples were soaked in cold water before washing twice in a commercial washing machine with cold water for 12-min cycles. Two bags for each treatment (0-h bags) were soaked for $30 \mathrm{~min}$ in warm water and washed with the rest of the sample bags. The bags were dried in a forced-air oven at $60^{\circ} \mathrm{C}$ for $48 \mathrm{~h}$. Residues were ground through a 1-mm Udy mill screen (Udy Corp., Boulder, CO) for nutrient analysis. Duplicates within cows were composited into one sample before nutrient analysis. Samples were sent to CVAS and analyzed for starch and NDF as described previously.

\section{Statistical Analysis}

Intake, lactation performance, digestibility, and sorting data were analyzed as a completely randomized design with the data from the preliminary period as a covariate using the PROC MIXED procedure of SAS (SAS Institute, 2004) with week of treatment as repeated measures using the first order autoregressive covariance structure that provided the best fit according to Sawa's Bayesian information criterion. Pen was used as the experimental unit. The model included treatment, period, and treatment by period interaction as fixed effects, and pen within treatment as a random effect. Degrees of freedom were calculated using the KenwardRogers option. Means were determined using the least squares means statement and treatment means were compared using the PDIFF option. Statistical significance and trends were considered at $P \leq 0.05$ and $P>$ 0.05 to $P \leq 0.10$, respectively. Body weight change and diet $\mathrm{NE}_{\mathrm{L}}$ data was calculated using the same model but did not include covariance or repeated measures.

To assess if dietary changes at wk 8 affected the results, preliminary data analysis was conducted using the same model but also including effects of period and treatment by period interaction. Period was divided into 1 and 2, where period 1 consisted of treatment wk 1 to 7 and period 2 consisted of treatment wk 8 to 14 . Because no period by treatment interaction was observed for any lactation performance parameter, period was not included in the final model. Furthermore, treatment by week interaction was still used in the final model to evaluate response variance over the $14 \mathrm{wk}$ of treatment, and no interactions were observed. Because neither period by treatment nor week by treatment interactions were observed, suggesting that dietary changes did not affect the results of the present experiment, data were presented combined rather than by period.

In situ data were analyzed as a completely randomized design using PROC MIXED (SAS Institute Inc., 2004). Cow was used as the experimental unit. The model included treatment, week, and treatment by week interaction as fixed effects and cow as a random effect. Statistical significance and trends were declared at $P \leq 0.05$ and $P>0.05$ to $P<0.10$, respectively.

\section{RESULTS AND DISCUSSION}

Nutrient composition and particle size of the diets are in Table 1. Except for lignin content, which was greater for the LFY diet, nutrient composition was similar for the 2 treatment diets during wk 1 to 7 . After replacement of wheat straw with WPCS in the LFY diet at wk 8, dietary lignin concentration was similar for the 2 treatments. Particle sizes of TMR were similar for the 2 treatments during the entire trial.

Corn silage nutrient composition, processing score, fermentation profile and particle size results are in Table 2; both hybrids were of good quality (Kung and Shaver, 2000; NRC, 2001) and of similar particle size, processing score and fermentation profile. Nutrient composition was similar between hybrids except for the lower lignin (2.3 vs. $2.8 \%$ on average) and uNDF (6.9 vs. $9.4 \%$ on average) concentrations for BMR compared with LFY. This resulted in a greater NDF $k_{d}$ $(4.8 \% / \mathrm{h}$ vs. $3.8 \% / \mathrm{h}$ on average) and 10.7 percentage units greater ruminal 30 -h in vitro NDF digestibility coefficient for BMR compared with LFY.

Ruminal in vitro starch digestibility coefficient (7 h) was 5.7 percentage units greater for LFY compared with BMR (Table 2). Likewise, a 10 percentage unit greater ruminal in situ starch digestibility coefficient (12 h) was observed $(P=0.01$; data not provided $)$ for LFY compared with BMR. This is in agreement with the chemical composition, physical property, and in vitro gas production results in Table 3 for LFY versus BMR unfermented corn kernels. Kernel vitreousness was more than 2-fold greater for BMR than LFY (90.0 vs. $37.5 \%$ ). A negative relationship between kernel vitreousness and starch digestibility has been previously reported in the literature (Philippeau and Michalet-Doreau, 1997; Correa et al., 2002). In vitro gas production from 0 to $12 \mathrm{~h}$ was also greater for LFY compared with BMR $(64.9 \pm 0.5 \%$ vs. $60.6 \pm 0.7 \%$ on average) kernels, suggesting a greater starch $\mathrm{k}_{\mathrm{d}}$. Kernel zein contents and profiles, however, were similar for the 2 hybrids. A positive relationship between zein content and vitreousness was previously reported by Philippeau et al. (2000) and Lopes et al. (2009) in corn grain. Data 
Table 2. Chemical composition, fermentation, and physical characteristics (means \pm SD) of whole plant corn silage $^{1,2}$

\begin{tabular}{|c|c|c|}
\hline Item & BMR & LFY \\
\hline \multicolumn{3}{|l|}{ Nutrient } \\
\hline DM, $\%$ of as fed & $37.7 \pm 2.5$ & $36.0 \pm 3.2$ \\
\hline $\mathrm{OM}, \%$ of $\mathrm{DM}$ & $94.4 \pm 0.6$ & $95.8 \pm 0.4$ \\
\hline $\mathrm{CP}, \%$ of $\mathrm{DM}$ & $8.7 \pm 0.2$ & $8.7 \pm 0.3$ \\
\hline Soluble CP, $\%$ of DM & $47.5 \pm 3.2$ & $50.0 \pm 4.8$ \\
\hline NDICP, $3 \%$ of DM & $1.1 \pm 0.1$ & $0.9 \pm 0.1$ \\
\hline $\mathrm{ADICP},{ }^{3} \%$ of DM & $0.8 \pm 0.1$ & $0.8 \pm 0.1$ \\
\hline Ether extract, $\%$ of DM & $3.4 \pm 0.3$ & $3.4 \pm 0.2$ \\
\hline $\mathrm{NDF}, \%$ of DM & $38.2 \pm 0.9$ & $36.0 \pm 1.6$ \\
\hline $\mathrm{ADF}, \%$ of $\mathrm{DM}$ & $21.6 \pm 0.5$ & $21.7 \pm 1.2$ \\
\hline Lignin, $\%$ of DM & $2.3 \pm 0.3$ & $2.8 \pm 0.2$ \\
\hline $\mathrm{uNDF},{ }^{4} \%$ of DM & $6.9 \pm 0.7$ & $9.4 \pm 0.3$ \\
\hline $30-\mathrm{h}$ IVNDFD ${ }^{5} \%$ of NDF & $67.9 \pm 0.8$ & $57.2 \pm 1.7$ \\
\hline \multicolumn{3}{|l|}{ NDF $\mathrm{k}_{\mathrm{d}}, 6 / \mathrm{h}$} \\
\hline Starch, \% of DM & $30.6 \pm 1.3$ & $32.2 \pm 1.2$ \\
\hline 7-h IVStarchD ${ }^{7} \%$ of starch & $69.9 \pm 3.2$ & $75.6 \pm 2.3$ \\
\hline Sugars, \% of DM & $2.0 \pm 0.4$ & $3.0 \pm 0.5$ \\
\hline \multicolumn{3}{|l|}{ Fermentation profile } \\
\hline $\mathrm{pH}$ & $3.93 \pm 0.11$ & $4.01 \pm 0.07$ \\
\hline Lactate, \% of DM & $4.94 \pm 0.80$ & $4.74 \pm 0.62$ \\
\hline Acetate, $\%$ of DM & $1.24 \pm 0.32$ & $1.17 \pm 0.09$ \\
\hline Propionate, $\%$ of DM & $<0.01$ & $<0.01$ \\
\hline Butyrate, $\%$ of DM & $<0.01$ & $<0.01$ \\
\hline Ethanol, \% of DM & $<0.01$ & $<0.01$ \\
\hline Ammonia, $\%$ of $\mathrm{CP}$ & $8.73 \pm 0.94$ & $9.15 \pm 0.09$ \\
\hline \multicolumn{3}{|l|}{ Minerals } \\
\hline $\mathrm{Ca}, \%$ of $\mathrm{DM}$ & $0.26 \pm 0.09$ & $0.22 \pm 0.04$ \\
\hline $\mathrm{P}, \%$ of $\mathrm{DM}$ & $0.26 \pm 0.01$ & $0.23 \pm 0.02$ \\
\hline $\mathrm{Mg}, \%$ of $\mathrm{DM}$ & $0.29 \pm 0.03$ & $0.25 \pm 0.04$ \\
\hline $\mathrm{K}, \%$ of $\mathrm{DM}$ & $1.20 \pm 0.11$ & $1.15 \pm 0.19$ \\
\hline \multicolumn{3}{|c|}{ Processing score ${ }^{8} \%$ passing $4,750-\mu \mathrm{m}$ sieve } \\
\hline Starch & $66.7 \pm 3.5$ & $67.4 \pm 3.2$ \\
\hline \multicolumn{3}{|c|}{ Penn State Separator Sieves, ${ }^{9} \%$ as-fed retained } \\
\hline 19 mm & $4.9 \pm 1.7$ & $5.8 \pm 1.7$ \\
\hline $8 \mathrm{~mm}$ & $65.5 \pm 2.8$ & $66.5 \pm 4.8$ \\
\hline $1.18 \mathrm{~mm}$ & $28.2 \pm 3.9$ & $26.4 \pm 5.0$ \\
\hline Bottom pan & $1.4 \pm 0.9$ & $1.3 \pm 1.1$ \\
\hline \multicolumn{3}{|c|}{${ }^{1}$ Treatments were brown midrib (BMR) or leafy-floury (LFY) hybrid. } \\
\hline \multicolumn{3}{|c|}{${ }^{2}$ Eight samples analyzed in duplicate per treatment. } \\
\hline \multicolumn{3}{|c|}{${ }^{3} \mathrm{NDICP}=$ neutral detergent-insoluble $\mathrm{CP} ; \mathrm{ADICP}=$ acid detergent-insoluble $\mathrm{CP}}$. \\
\hline \multicolumn{3}{|c|}{${ }^{4}$ Undigested NDF after $240 \mathrm{~h}$ of incubation. } \\
\hline \multicolumn{3}{|c|}{${ }^{5}$ Ruminal in vitro NDF digestibility at $30 \mathrm{~h}$. } \\
\hline \multicolumn{3}{|c|}{${ }^{6}$ Rate of NDF digestion calculated as described by Van Amburgh et al. (2003). } \\
\hline \multicolumn{3}{|c|}{${ }^{7}$ Ruminal in vitro starch digestibility at $7 \mathrm{~h}$. } \\
\hline \multicolumn{3}{|c|}{${ }^{8}$ Processing score was measured as described by Ferreira and Mertens (2005). } \\
\hline
\end{tabular}

comparing WPCS hybrids, however, are limited, and further research is necessary to better understand the relationship among kernel vitreousness, zein protein, and starch digestibility in WPCS hybrids. Kernel DM content was 9.3 percentage units greater for BMR than LFY. Accumulation of DM in the kernels has varied among hybrids at a similar harvest stage in other trials (Ngonyamo-Majee et al., 2008, 2009). Greater starch and lower $\mathrm{CP}$ concentrations were observed for BMR than LFY kernels in relationship to the greater DM content for BMR kernels (Philippeau and MichaletDoreau, 1997). Variation in DM and nutrient contents between hybrids suggest that recommendations for harvesting based on maturity may vary depending on the hybrid grown.

Treatment effects on covariate-adjusted least squares means for intake and lactation performance are in Table 4. Cows fed BMR had $1.7 \mathrm{~kg} / \mathrm{d}$ greater $(P=$ 0.01) DMI than cows fed LFY as a results of the lower lignin and $\mathrm{uNDF}$ contents and corresponding greater ruminal in vitro NDF digestibility of BMR WPCS (Table 2; Oba and Allen, 1999). In addition, the benefit to feeding BMR on DMI is more pronounced when high forage-NDF diets are fed (Oba and Allen, 2000a; Qiu 
Table 3. Chemical composition and in vitro gas production for unfermented corn kernels ${ }^{1,2}$

\begin{tabular}{|c|c|c|}
\hline Item & BMR & LFY \\
\hline \multicolumn{3}{|l|}{ Nutrient } \\
\hline DM, $\%$ of as fed & 66.8 & 57.5 \\
\hline $\mathrm{CP}, \%$ of $\mathrm{DM}$ & 8.6 & 10.1 \\
\hline Soluble CP, $\%$ of DM & 2.4 & 2.8 \\
\hline Soluble CP, $\%$ of $\mathrm{CP}$ & 28.2 & 27.9 \\
\hline NDF, $\%$ of DM & 6.7 & 7.1 \\
\hline Starch, \% of DM & 72.8 & 69.6 \\
\hline Ether extract, \% of DM & 3.1 & 3.9 \\
\hline Ash, $\%$ of DM & 1.3 & 1.4 \\
\hline \multicolumn{3}{|l|}{ Endosperm } \\
\hline Vitreousness, $\%$ of endosperm & 90.0 & 37.5 \\
\hline \multicolumn{3}{|l|}{ Zein protein profile } \\
\hline Total zein, $\%$ of DM & 3.5 & 3.7 \\
\hline Total zein, $\%$ of CP & 40.5 & 37.0 \\
\hline Total zein, $\%$ of starch & 4.8 & 5.4 \\
\hline$\alpha$ zein, $\%$ of DM & 2.3 & 2.4 \\
\hline$\alpha$ zein, $\%$ of $\mathrm{CP}$ & 26.8 & 23.7 \\
\hline$\alpha$ zein, $\%$ of starch & 3.2 & 3.4 \\
\hline$\alpha$ zein, $\%$ of zein & 66.1 & 64.1 \\
\hline$\beta, \gamma, \delta$ zein, $\%$ of $\mathrm{DM}$ & 1.2 & 1.3 \\
\hline$\beta, \gamma, \delta$ zein, $\%$ of $\mathrm{CP}$ & 13.7 & 13.3 \\
\hline$\beta, \gamma, \delta$ zein, $\%$ of starch & 1.6 & 1.9 \\
\hline$\beta, \gamma, \delta$ zein, $\%$ of zein & 33.9 & 35.9 \\
\hline \multicolumn{3}{|l|}{ In vitro gas production ${ }^{3}$} \\
\hline $\mathrm{PAR}, \mathrm{mL} / 0.1 \mathrm{~g}$ of $\mathrm{DM} / \mathrm{h}$ & 2.3 & 2.2 \\
\hline Time of PAR, $h$ & 7.8 & 8.5 \\
\hline Maximum cumulative gas, $\mathrm{mL} / 0.1 \mathrm{~g}$ of $\mathrm{DM}$ & 32.0 & 31.8 \\
\hline $0-12 \mathrm{~h}$ gas production, $\%$ & 60.6 & 64.9 \\
\hline $12-24 \mathrm{~h}$ gas production, $\%$ & 39.4 & 35.1 \\
\hline
\end{tabular}

${ }^{1}$ Treatments were diet containing brown midrib (BMR) or leafy-floury (LFY) hybrid.

${ }^{2}$ Two samples analyzed in duplicate per treatment.

${ }^{3} \mathrm{PAR}=$ peak absolute rate.

et al., 2003), such as in the present study [25.7\% forage NDF (DM basis) on average], which may limit intake through reduced ruminal fiber disappearance and increased fill (Mertens, 1987; Ferraretto et al., 2013). In the present study, however, total-NDF intake and forage-NDF intake, respectively, were 1.16 and $0.94 \%$ of BW for cows fed LFY and 1.12 and $1.01 \%$ of BW for cows fed BMR (data not provided), and not indicative of a rumen fill limitation of DMI (Mertens, 1987). Furthermore, the removal of wheat straw from the LFY diet at wk 8 of the treatment period equalized treatment diets for lignin and forage uNDF contents (Table 1 ), but the DMI difference between treatments was not altered, suggesting that factors other than rumen fill were involved. Alternatively, dairy cows can selectively retain potentially digestible NDF (pdNDF) in the rumen compared with uNDF (Lund et al., 2007). Although ruminal passage rate was not measured in our trial, Oba and Allen (2000b) reported greater ruminal passage rate of uNDF but not pdNDF when cows were fed BMR compared with non-BMR WPCS. These authors associated the increased uNDF passage rate with greater fragility of plant cell walls in BMR and the cor-
Table 4. Effect of treatment on covariate-adjusted least squares means for intake and lactation performance $\mathrm{c}^{1,2,3}$

\begin{tabular}{lccll}
\hline Item & BMR & LFY & SE & $P$-value \\
\hline Intake & & & & \\
DM, kg/d & 28.1 & 26.4 & 0.4 & 0.01 \\
DM, \% of BW & 3.82 & 3.64 & 0.05 & 0.01 \\
OM, kg/d & 24.7 & 23.2 & 0.4 & 0.01 \\
NDF, kg/d & 7.9 & 7.7 & 0.1 & 0.10 \\
Starch, kg/d & 6.1 & 5.5 & 0.1 & 0.001 \\
CP, kg/d & 4.7 & 4.2 & 0.1 & 0.001 \\
Yield & & & & \\
Milk, kg/d & 49.0 & 46.8 & 0.8 & 0.05 \\
3.5\% FCM, kg/d & 50.8 & 49.7 & 0.8 & 0.20 \\
SCM, kg/d & 46.8 & 45.3 & 0.7 & 0.06 \\
ECM, kg/d & 50.5 & 49.0 & 0.7 & 0.07 \\
Milk component & & & & \\
Fat, \% & 3.83 & 4.05 & 0.07 & 0.01 \\
Fat, kg/d & 1.84 & 1.84 & 0.04 & 0.89 \\
Protein, \% & 3.27 & 3.27 & 0.08 & 0.98 \\
Protein, kg/d & 1.57 & 1.48 & 0.03 & 0.03 \\
Lactose, \% & 4.87 & 4.81 & 0.03 & 0.06 \\
Lactose, kg/d & 2.35 & 2.19 & 0.05 & 0.01 \\
MUN, mg/dL & 15.6 & 16.8 & 0.3 & 0.001 \\
\hline
\end{tabular}

${ }^{1}$ Treatments were diet containing brown midrib (BMR) or leafy-floury (LFY) hybrid.

${ }^{2}$ Week effect $(P<0.01)$ for milk fat, protein, lactose, and urea-nitrogen concentration and lactose yield.

${ }^{3}$ Nonsignificant $(P>0.10)$ week $\times$ treatment interaction for all parameters.

responding greater particle size reduction in the rumen. Disruption of plant cell wall and digestion of pdNDF enhances particle density and thereby increases passage rate of uNDF particles (Wattiaux et al., 1991). Further research is warranted to elucidate all the mechanisms related to the increase in DMI when cows are fed BMR.

Coincident with DMI, intakes of $\mathrm{OM}, \mathrm{CP}$, and starch were $(P<0.01) 1.5,0.5$, and $0.6 \mathrm{~kg} / \mathrm{d}$ greater for cows fed BMR compared with LFY. Likewise, NDF intake tended $(P=0.10)$ to be greater for BMR than LFY. Despite differences in intake, feed sorting was minimal and did not differ $(P>0.10)$ between treatments (data not provided). Similar results were observed by Ebling and Kung (2004) and Gehman et al. (2008). Long particles were selectively refused ( $97.9 \%$ on average), but not medium or short particles $(99.4$ and $100.6 \%$ on average, respectively). Conversely, selective consumption of fine particles (101.4\% on average) was observed.

Treatment effects on covariate-adjusted least squares means for lactation performance measurements are in Table 4 . Milk yield was $2.2 \mathrm{~kg} / \mathrm{d}$ greater $(P=0.05)$ for $\mathrm{BMR}$ and related to greater $\mathrm{DM}$ and nutrient intakes for BMR than LFY. Despite the alteration in the LFY diet at wk 8, the milk yield difference between treatments was consistent throughout the trial. Greater milk yield when cows were fed BMR WPCS was previously reported by others (Oba and Allen, 2000a; Holt et al., 2013). In addition, a positive relationship between 
Table 5. Effect of treatment on covariate-adjusted least squares means for BW, BCS, and feed conversion, and unadjusted means for BW change and estimated diet energy concentrations $\mathrm{s}^{1,2,3}$

\begin{tabular}{lcccc}
\hline Item & BMR & LFY & SE & $P$-value \\
\hline BW, kg & 740.1 & 734.2 & 7.3 & 0.44 \\
BW change, kg/d & 0.32 & 0.39 & 0.14 & 0.63 \\
BCS & 3.16 & 3.10 & 0.06 & 0.32 \\
Feed conversion & & & & \\
kg of milk/kg of DMI & 1.75 & 1.76 & 0.04 & 0.82 \\
$\mathrm{~kg}$ of $3.5 \%$ FCM $/ \mathrm{kg}$ of DMI & 1.81 & 1.85 & 0.03 & 0.25 \\
$\mathrm{~kg}$ of SCM/kg of DMI & 1.67 & 1.69 & 0.03 & 0.55 \\
$\mathrm{~kg}$ of ECM/kg of DMI & 1.80 & 1.83 & 0.03 & 0.38 \\
Estimated diet energy content, ${ }^{4}$ Mcal/kg of DMI & 1.72 & 1.78 & 0.04 & 0.18 \\
\hline
\end{tabular}

${ }^{1}$ Treatments were diet containing brown midrib (BMR) or leafy-floury (LFY) hybrid.

${ }^{2}$ Week effect for feed conversion $(P<0.001)$, and BW change $(P<0.10)$.

${ }^{3}$ Nonsignificant $(P>0.10)$ week $\times$ treatment interaction for all parameters.

${ }^{4}$ Calculated by summing the megacalories of $\mathrm{NE}_{\mathrm{L}}$ from milk production, required for maintenance, and in $\mathrm{BW}$ change (NRC, 2001) and then dividing the sum by DMI.

DMI and milk yield has been documented in a recent research review (Ferraretto et al., 2013). Despite the increase in milk yield, both $3.5 \%$ FCM and milk fat yield were unaffected $(P>0.10)$ by treatment due to reduced milk fat concentration (3.83 vs. $4.05 \%$; $P=$ 0.01) for cows fed BMR. Lower milk fat concentration is in agreement with previous literature comparing BMR with non-BMR WPCS (Oba and Allen, 2000a; Ramirez et al., 2012).

Cows fed BMR, however, had $(P<0.05)$ greater yields of milk protein and lactose compared with LFY and thereby tended to increase $(P<0.10)$ both ECM and SCM by $1.5 \mathrm{~kg} / \mathrm{d}$. This is related to greater DM and nutrient intakes (Table 4; NRC, 2001) and potentially greater flow $(\mathrm{g} / \mathrm{d})$ of microbial protein to the duodenum (NRC, 2001). Although microbial protein synthesis was not measured in the present study, it was previously reported to be both greater and more efficient for cows fed diets containing BMR compared with non-BMR WPCS (Oba and Allen, 2000b; Ramirez et al., 2012) and may be related to more rumen ammonia being incorporated into microbial protein (Oba and Allen, 2000b). The lower MUN concentration observed ( $P$ $=0.001)$ for the BMR treatment supports this premise and is consistent with previous literature (Qiu et al., 2003; Ramirez et al., 2012).

Treatment effects on covariate-adjusted least squares means for BW, BCS, and feed conversions, and unadjusted means for BWC and estimated diet energy concentrations are in Table 5. Body weight, BWC, and BCS were unaffected by treatment $(P>0.10)$, which suggests that energy partitioning to or from adipose tissue did not affect our results. Feed conversion for milk, 3.5\% FCM, ECM, and SCM were similar $(P>$ $0.10)$ between treatments. Similar FCM feed conversion was previously reported by others (Oba and Allen, 2000a; Ebling and Kung, 2004; Holt et al., 2013) when comparing BMR and non-BMR WPCS. Estimated diet energy content (Mcal of $\mathrm{NE}_{\mathrm{L}} / \mathrm{kg}$ of $\mathrm{DM}$ ), calculated using ECM, BW, BWC, and DMI data did not differ $(P$ $>0.10$ ) by treatment. These data support our premise that milk yield was primarily driven by the greater DM and nutrient intakes for BMR compared with LFY in agreement with Tine et al. (2001).

Treatment effects on least squares means for totaltract apparent nutrient digestibility coefficients are in Table 6. Cows fed LFY had 2 percentage units, on average, greater $(P<0.05)$ apparent $\mathrm{DM}$ and $\mathrm{OM}$ digestibility coefficients compared with BMR. The literature is inconsistent with reports of lower (Oba and Allen, 2000b), similar (Qiu et al., 2003; Ebling and Kung, 2004), or greater (Ramirez et al., 2012) DM and OM digestibility coefficients for BMR compared with nonBMR WPCS. A negative relationship between DMI and $\mathrm{OM}$ digestibility was reported in the reviews of Huhtanen et al. (2009) and Ferraretto et al. (2013), and may explain the results of the present study. Although no difference $(P>0.10)$ in overall total-tract apparent NDF digestibility coefficient (NDFD) was observed, NDFD was 4.6 percentage units greater $(P=0.03)$ for BMR than LFY diets during wk 13 of treatment (42.8 vs. $38.2 \%$ of NDF intake, respectively; data not shown). This is in agreement with our measurements of ruminal in situ NDF digestibility coefficient, although the magnitude of the difference was 6 percentage units less on average for NDFD compared with ruminal NDF digestibility coefficient measured in situ. The literature is inconsistent with reports of similar (Oba and Allen, 2000b; Qiu et al., 2003) or greater (Ebling and Kung, 2004; Ramirez et al., 2012) NDFD when cows were fed BMR compared with non-BMR WPCS. Lower magnitude of the difference between NDF digestibility coefficients measured in vivo versus in situ was previously reported by Oba and Allen (1999). This may be 
Table 6. Effect of treatment on covariate-adjusted least squares means for nutrient intake during digestibility weeks and apparent total-tract nutrient digestibility $1,2,3,4$

\begin{tabular}{lrrrl}
\hline Item & BMR & LFY & SE & $P$-value \\
\hline Intake, kg/d & & & & \\
DM & 27.6 & 26.8 & 0.4 & 0.21 \\
OM & 25.5 & 24.8 & 0.4 & 0.20 \\
CP & 4.7 & 4.3 & 0.1 & 0.01 \\
NDF & 9.2 & 8.7 & 0.1 & 0.02 \\
Starch & 5.8 & 5.6 & 0.1 & 0.25 \\
Digestibility, \% of intake & & & & \\
DM & 60.7 & 62.8 & 0.8 & 0.03 \\
OM & 62.8 & 65.0 & 0.7 & 0.02 \\
CP & 57.2 & 57.4 & 0.6 & 0.75 \\
NDF & 40.4 & 39.7 & 1.9 & 0.73 \\
Starch & 93.3 & 98.0 & 0.7 & 0.001 \\
\hline
\end{tabular}

${ }^{1}$ Treatments were diet containing brown midrib (BMR) or leafy-floury (LFY) hybrid.

${ }^{2}$ Week effect observed only for intake of DM $(P<0.10)$, OM $(P<$ $0.08)$, NDF $(P<0.001)$, and starch $(P<0.03)$; and digestibility of $\mathrm{CP}(P<0.08)$.

${ }^{3}$ Week $\times$ treatment interaction effect observed only for digestibility of NDF $(P<0.02)$.

${ }^{4}$ Determined using lignin as an internal marker.

related to NDFD measurements being performed on TMR, whereas in situ measurements were performed on WPCS by cows fed a diet containing nonexperimental corn silage. Tine et al. (2001) reported greater NDFD for BMR diets $31.3 \% \mathrm{NDF}$ and $1.11 \%$ lignin, DM basis) compared with diets composed of an isogenic WPCS (32.0\% NDF and $1.78 \%$ lignin, DM basis) when cows were fed diets at restricted levels but not when fed for ad libitum consumption. These data suggest that increased rate of passage as a consequence of greater DMI (Huhtanen et al., 2009) for cows fed BMR may have contributed to the difference between in situ and in vivo measurements.

A 4.7 percentage unit increase $(P=0.001)$ in totaltract apparent starch digestibility coefficient was observed for LFY compared with BMR. The starch portion of LFY WPCS was more digestible than BMR as observed by ruminal in vitro and in situ starch digestibility coefficients (Table 2). Additionally, greater DMI for cows fed BMR may have resulted in increased passage rate and thereby lower starch digestibility (Firkins et al., 2001; Ferraretto et al., 2013). Total-tract apparent $\mathrm{CP}$ digestibility coefficients did not differ $(P$ $>0.10)$ between treatments and is in agreement with previous literature (Oba and Allen, 2000b; Qiu et al., 2003; Ebling and Kung, 2004).

Ruminal in situ starch digestibility coefficient was 10 percentage units greater for LFY than BMR after a 12 -h incubation (97.5 vs. $87.6 \%$, respectively; $P=$ 0.01 ; data not presented), in concurrence with the 6 percentage units greater ruminal vitro starch digestibility coefficient ( $7 \mathrm{~h}$; Table 2$)$. Starch digestibility of the BMR was inhibited by vitreousness, despite the similar kernel zein protein contents and profiles for the 2 treatments (Table 3). Philippeau and MichaletDoreau (1997) observed a negative relationship between ruminal in situ starch digestibility and vitreousness of WPCS supporting our premise. In contrast, greater $(P$ $=0.05)$ ruminal in situ NDF digestibility coefficient was observed for BMR than LFY on samples collected during wk 13 (52.6 vs. $41.8 \%$ of NDF, respectively), but not wk $7(P>0.10)$ of the lactation study (data not presented), in agreement with NDFD (data not shown) and in vitro (30 h; Table 2) data. Presumably, the lower lignin content for BMR compared with LFY (Table 2) and corresponding decreased cross-linkage with other fiber compounds resulted in greater microbial access and therefore greater NDF digestibility (Jung et al., 2012). Increased NDF digestibility for BMR compared with non-BMR WPCS was reported by Ebling and Kung (2004).

\section{CONCLUSIONS}

Apparent total-tract starch digestibility was increased by 5 percentage units in high-producing dairy cows fed LFY compared with BMR in concurrence with greater ruminal in vitro and situ starch digestibilities for LFY. Although feed conversions were not different, DMI and milk and protein yields were decreased, however, for LFY compared with a BMR. Results in the present study imply that WPCS hybrid selection programs, which focus on increasing starch digestibility by dairy cows through selection of softer kernel texture, are feasible. Furthermore, these results denote the importance of NDF digestibility in WPCS hybrid selection programs. Further research is warranted to evaluate LFY compared with conventional WPCS hybrids to assess economic impacts of greater starch digestibility in corn silage.

\section{ACKNOWLEDGMENTS}

Appreciation is extended to Glenn Seed Ltd. (Blenheim, ON, Canada) for partial project funding; the staff at the University of Wisconsin-Madison Agricultural Research Station for corn production and corn silage harvest and storage; Mike Peters and Sandy Trower and their staff at the University of Wisconsin Madison Blaine Dairy Cattle Center for animal care and trial management; Shane Fredin, Fernanda Lopes, Robb Bender, and Tiago Barros (University of WisconsinMadison) for assistance during fecal samples collection; and West Central Cooperative (Ralston, IA) for donating the SoyPLUS. 


\section{REFERENCES}

AOAC International. 2006. Official Methods of Analysis. 18th ed. AOAC International, Arlington, VA.

Baker, S., and T. Herrman. 2002. Evaluating particle size. MF-2051. Kansas State Univ. Coop Ext. Serv. Manhattan.

Correa, C. E. S., R. D. Shaver, M. N. Pereira, J. G. Lauer, and K. Kohn. 2002. Relationship between corn vitreousness and ruminal in situ starch degradability. J. Dairy Sci. 85:3008-3012.

Der Bedrosian, M. C., L. Kung Jr., and K. E. Nestor Jr.. 2012. The effects of hybrid, maturity and length of storage on the composition and nutritive value of corn silage. J. Dairy Sci. 95:5115-5126.

Ebling, T. L., and L. Kung Jr.. 2004. A comparison of processed conventional corn silage to unprocessed and processed brown midrib corn silage on intake, digestion, and milk production by dairy cows. J. Dairy Sci. 87:2519-2526.

Ferraretto, L. F., P. M. Crump, and R. D. Shaver. 2013. Effect of cereal grain type and corn grain harvesting and processing methods on intake, digestion, and milk production by dairy cows through a meta-analysis. J. Dairy Sci. 96:533-550.

Ferraretto, L. F., and R. D. Shaver. 2012a. Effect of corn shredlage on lactation performance and total tract starch digestibility by dairy cows. Prof. Anim. Sci. 28:639-647.

Ferraretto, L. F., and R. D. Shaver. 2012b. Meta-analysis: Impact of corn silage harvest practices on intake, digestion and milk production by dairy cows. Prof. Anim. Sci. 28:141-149.

Ferraretto, L. F., R. D. Shaver, and S. J. Bertics. 2012. Effect of dietary supplementation with live-cell yeast at two dosages on lactation performance, ruminal fermentation, and total-tract nutrient digestibility in dairy cows. J. Dairy Sci. 95:4017-4028.

Ferreira, G., and D. R. Mertens. 2005. Chemical and physical characteristics of corn silages and their effects on in vitro disappearance. J. Dairy Sci. 88:4414-4425.

Firkins, J. L., M. L. Eastridge, N. R. St-Pierre, and S. M. Noftsger. 2001. Effects of grain variability and processing on starch utilization by lactating dairy cattle. J. Anim. Sci. 79(E. Suppl.):E218E238.

Gehman, A. M., P. J. Kononoff, C. R. Mullins, and B. N. Janicek. 2008. Evaluation of nitrogen utilization and the effects of monensin in dairy cows fed brown midrib corn silage. J. Dairy Sci. 91:288-300.

Gencoglu, H., R. D. Shaver, W. Steinberg, J. Ensink, L. F. Ferraretto, S. J. Bertics, J. C. Lopes, and M. S. Akins. 2010. Effect of feeding a reduced-starch diet with or without amylase addition on lactation performance in dairy cows. J. Dairy Sci. 93:723-732.

Goering, H. K., and P. J. Van Soest. 1970. Pages 8-11 in Forage Fiber Analyses (Apparatus, Reagents, Procedures, and Some Applications). Agric. Handbook No. 379. ARS-USDA, Washington, DC.

Hall, M. B. 2009. Analysis of starch, including maltooligosaccharides in animal feeds: A comparison of methods and a recommended method for AOAC collaborative study. J. Assoc. Off. Anal. Chem. 92:42-49.

Hoffman, P. C., D. R. Mertens, J. Larson, W. K. Coblentz, and R. D Shaver. 2012. A query for effective mean particle size of dry and high moisture corns. J. Dairy Sci. 95:3467-3477.

Holt, M. S., J.-S. Eun, C. R. Thacker, A. J. Young, X. Dai, and K. E. Nestor Jr.. 2013. Effects of feeding brown midrib corn silage with a high dietary concentration of alfalfa hay on lactational performance of Holstein dairy cows for the first 180 days of lactation. J. Dairy Sci. 96:515-523.

Huhtanen, P., M. Rinne, and J. Nousiainen. 2009. A meta-analysis of feed digestion in dairy cows. 2 . The effects of feeding level and diet composition on digestibility. J. Dairy Sci. 92:5031-5042.

Jung, H. J., D. A. Samac, and G. Sarath. 2012. Modifying crops to increase cell wall digestibility. Plant Sci. 185:65-77.

Kononoff, P. J., A. J. Heinrichs, and D. R. Buckmaster. 2003. Modification of the Penn State forage and total mixed ration particle separator and the effects of moisture content on its measurements. J. Dairy Sci. 86:1858-1863.

Kotarski, S. F., R. D. Waniska, and K. K. Thurn. 1992. Starch hydrolysis by the ruminal microflora. J. Nutr. 122:178-190.
Krishnamoorthy, U., T. V. Muscato, C. J. Sniffen, and P. J. Van Soest. 1982. Borate phosphate procedure as detailed in nitrogen fractions in selected feedstuffs. J. Dairy Sci. 65:217-225.

Kung, L., and R. Shaver. 2000. Interpretation and use of silage fermentation analysis report. Accessed May 9, 2012. http://www. sciencedirect.com/science/article/pii/S0022030208712323.

Leonardi, C., and L. E. Armentano. 2003. Effect of quantity, quality and length of alfalfa hay on selective consumption by dairy cows. J. Dairy Sci. 86:557-564.

Lopes, J. C., R. D. Shaver, P. C. Hoffman, M. S. Akins, S. J. Bertics, H. Gencoglu, and J. G. Coors. 2009. Type of corn endosperm influences nutrient digestibility in lactating dairy cows. J. Dairy Sci. 92:4541-4548.

Lund, P., M. R. Weisbjerg, and T. Hvelplund. 2007. Digestible NDF is selectively retained in the rumen of dairy cows compared to indigestible NDF. Anim. Feed Sci. Technol. 134:1-17.

Masoero, F., A. Gallo, C. Zanfi, G. Giuberti, and M. Spanghero. 2011 Effect of nitrogen fertilization on chemical composition and rumen fermentation of different parts of plants of three corn hybrids. Anim. Feed Sci. Technol. 164:207-216.

McAllister, T. A., R. C. Phillippe, L. M. Rode, and K. J. Cheng. 1993 Effect of the protein matrix on the digestion of cereal grains by ruminal microorganisms. J. Anim. Sci. 71:205-212.

Mertens, D. R. 1987. Predicting intake and digestibility using mathematical models of ruminal function. J. Anim. Sci. 64:1548-1558.

Nellis, S. E., P. C. Hoffman, and R. D. Shaver. 2013. Technical note: A modified method to quantify prolamin proteins in dry and highmoisture corn. J. Dairy Sci. 96:4647-4652.

Ngonyamo-Majee, D., R. D. Shaver, J. G. Coors, D. Sapienza, and J. G. Lauer. 2008. Relationship between kernel vitreousness and DM degradability for diverse corn germplasm. II. Ruminal and postruminal degradabilities. Anim. Feed Sci. Technol. 142:259-274.

Ngonyamo-Majee, D., R. D. Shaver, J. G. Coors, D. Sapienza, and J G. Lauer. 2009. Influence of single-gene mutations, harvest maturity and sample processing on ruminal in situ and post-ruminal in vitro dry matter and starch degradability of corn grain by ruminants. Anim. Feed Sci. Technol. 151:240-259.

NRC. 2001. Nutrient Requirements of Dairy Cattle. 7th rev. ed. Natl. Acad. Sci., Washington, DC.

Oba, M., and M. S. Allen. 1999. Evaluation of the importance of the digestibility of neutral detergent fiber from forage: effects on dry matter intake and milk yield of dairy cows. J. Dairy Sci. $82: 589-596$.

Oba, M., and M. S. Allen. 2000a. Effects of brown midrib 3 mutation in corn silage on productivity of dairy cows fed two concentrations of dietary neutral detergent fiber: 1 . feeding behavior and nutrient utilization. J. Dairy Sci. 83:1333-1341.

Oba, M., and M. S. Allen. 2000b. Effects of brown midrib 3 mutation in corn silage on productivity of dairy cows fed two concentrations of dietary neutral detergent fiber: 3 . digestibility and microbial efficiency. J. Dairy Sci. 83:1350-1358.

Philippeau, C., J. Landry, and B. Michalet-Doreau. 2000. Influence of the protein distribution of maize endosperm on ruminal starch degradability. J. Sci. Food Agric. 80:404-408.

Philippeau, C., and B. Michalet-Doreau. 1997. Influence of genotype and stage of maturity of maize on rate of ruminal starch degradation. Anim. Feed Sci. Technol. 68:25-35.

Qiu, X., M. L. Eastridge, and Z. Wang. 2003. Effects of corn silage hybrid and dietary concentration of forage NDF on digestibility and performance by dairy cows. J. Dairy Sci. 86:3667-3674.

Ramirez, H. A. R., K. Nestor, L. O. Tedeschi, T. R. Callaway, S. E. Dowd, S. C. Fernando, and P. J. Kononoff. 2012. The effect of brown midrib corn silage and dried distillers' grains with solubles on milk production, nitrogen utilization and microbial community structure in dairy cows. Can. J. Anim. Sci. 92:365-380.

Richards, C. J., J. F. Peterson, R. A. Britton, R. A. Stock, and C. R. Krehbiel. 1995. In vitro starch disappearance procedure modifications. Anim. Feed Sci. Technol. 55:35-45.

SAS Institute Inc. 2004. SAS/STAT 9.1 User's Guide. Version 9.1 ed. SAS Institute Inc., Cary, NC. 
Shere, B., N. Thiex, and M. Wolf. 2006. National forage testing association reference method: Dry matter by oven drying for 3 hours at $105^{\circ} \mathrm{C}$. NFTA Reference Methods. National Forage Testing Association, Omaha, NE.

Tine, M. A., K. R. McLeod, R. A. Erdman, and R. L. Baldwin VI.. 2001. Effects of brown midrib corn silage on the energy balance of dairy cattle. J. Dairy Sci. 84:885-895.

Tylutki, T. P., D. G. Fox, V. M. Durbal, L. O. Tedeschi, J. B. Russell, M. E. Van Amburgh, T. R. Overton, L. E. Chase, and A. N. Pell. 2008. Cornell net carbohydrate and protein system: A model for precision feeding of dairy cattle. Anim. Feed Sci. Technol. $143: 174-202$

Van Amburgh, M. E., P. J. Van Soest, J. B. Robertson, and W. F. Knaus. 2003. Corn silage neutral detergent fiber: Refining a mathematical approach for in vitro rates of digestion. Pages 99-108 in Proc. Cornell Nutr. Conf., Syracuse, NY. Department of Animal Science, Cornell University, Ithaca, NY.
Van Soest, P. J., J. B. Robertson, and B. A. Lewis. 1991. Methods for dietary fiber, neutral detergent fiber, and nonstarch polysaccharides in relation to animal nutrition. J. Dairy Sci. 74:3583-3597.

Vivek, B. S., A. F. Krivanek, N. Palacios-Rojas, S. Twumasi-Afriyie, and A. O. Diallo. 2008. Breeding Quality Protein Maize (QPM): Protocols for developing QPM cultivars. CIMMYT, Mexico.

Wattiaux, M. A., D. R. Mertens, and L. D. Satter. 1991. Effect of source and amount of fiber on kinetics of digestion and specific gravity of forage particles in the rumen. J. Dairy Sci. 74:38723883.

Wildman, E. E., G. M. Jones, P. E. Wagner, R. L. Boman, H. F. Troutt, and T. N. Lesch. 1982. A dairy-cow body condition scoring system and its relationship to selected production characteristics. J. Dairy Sci. 65:495-501. 